\title{
BİREYSEL MUTLULUK İLE BİREYSEL İŞ PERFORMANSI ARASINDA DOĞRUSAL BİR İLIŞKİ VAR MIDIR?
}

\author{
Mustafa ŞEHIRLI ${ }^{1}$ \\ Ziya TAŞKENT ${ }^{2}$
}

\author{
Received Date (Başvuru Tarihi): 16/04/2017 \\ Accepted Date (Kabul Tarihi): 08/08/2017 \\ Published Date (Yayın Tarihi): 25/08/2017
}

ÖZ

Bu çalışmada, felsefi bir mesele olarak insanoğlunu tarihi boyunca meşgul etmiş mutluluk kavramının bireysel yönü ile işletme örgütlerinde yer alan iş görenlerin bireysel performansı arasında doğrusal bir ilişkinin bulunup bulunmadığı araştırılmıştır. Çalışmada, Türk Hava Yolları'nın beyaz yakalı çalışanları arasında Fordy Duygu Ölçeri kullanılarak anket yapılmış, sonuçlar söz konusu iş görenlerin birinci amirleri tarafindan verilen bireysel performans puanları ile karşılaştırılmıştır. İişkinin varlığını sorgulamak amacıyla frekans ve Ki-kare analizleri uygulanmıştır. Sonuç olarak herne kadarbireysel mutluluk ile iş gören performansı arasında bir ilişk iden söz edilebilse de bunu bilimsel kabul etmek mümkün değildir. Çünkü algısal bir değişken olarak mutluluk ka vramı ancak genişletilmiş bir soru seti ölçülmelidir.

Anahtar Kelimeler: Bireysel; Mutluluk; Performans.

Jel Kodlart:D10, J10

\section{IS THERE A LINEAR RELATIONSHIP BETWEEN INDIVIDUAL HAPPINESS AND INDIVIDUAL BUSINESS PERFORMANCE?}

\section{ABSTRACT}

In this study, the individual perspective of the term happiness, which has been questioned as a philosophical matter throughout the human history, and employees' individual performance within business organizations have been observed to identify whether there is a direct relation or not. By using the Fordy Emotion Meter, a survey was conducted among white collar employees in Turkish Airlines Inc. and the outcomes of the survey was compared with the scores given by superior managers to those employees. In order to examine the existence of this relation; the frequency and Chi-square analysis have been implemented in the study. As a result, although it can be said that there is a relation between individual happiness and employee's performance, it cannot be accepted as scientific. Becuase the concept happiness as a perceptual variable has to be measured just through an expanded quastionnaire.

Keywords: Individual; Happiness; Performance.

Jel Classification: D10, J10

\footnotetext{
${ }^{1}$ Yrd. Doç. Dr., Sağlık Bilimleri Üniversitesi, Mustafasafrani@ gmail.com

2 taskentz@gmail.com
} 


\section{GİRIŞ}

Mutluluk, insanlk tarihi boyunca elde etmek amaciyla peşinde koşulan, felsefi boyutta tartışlan, psikolojinin konusu olmuş tümel bir kavramdır. "Sokrates'in mutluluğu, iyi yaşamın hedefi ilan ettiği andan itibaren insanlar mutluluğun sırrıı aradılar ve aramaya devam edeceklerdir.'(Macmahon, Darrin M., 2006, 478) Böylesine geniş ve çokça irdelenmiş bir konuda yeni bir fikir ortaya koymak iddiasmda bulunmak oldukça güçtür. Bununla birlikte işletme bilimi içinde mutluluk kavramını yeterince ele alındığını da söyleyemeyiz. İşletme dalında bu konuda yapılııı̧ çalışma sayısı oldukça azdır. Mutluluk kavramına dair literatür taraması yapıldığında ulaşılan çalışmalar ağıllıkı olarak meseleyi, psikoloji, felsefe ya da tarih disiplini içinde ele almaktadır.

Örgütler insanlarla doğar, gelişir veya ortadan kalkar. $\mathrm{Bu}$ nedenle örgütlerin temeli ve varlklarının dayanağı, insan unsurudur. Örgüt yönetiminde, insan unsuru üzerinde yoğunlaşılması, iş görenlerin istek, beklenti ve ihtiyaçlarının dikkate alınması önem taşımaktadır. Çünkü istek, beklenti ve ihtiyaçları dikkate alınmayan insan gücünün örgüt amaçları doğrultusunda harekete geçirilebilmesi ve ondan istenen verimin alınabilmesi güçtür. İnsan gücünün örgüt amaçlarına ulaşma doğrultusunda motive edilmesi, iş görenlerin kendilerini hem fiziksel hem de psikolojik olarak örgüt içinde sağllkh ve mutlu hissetmesi ile mümkündür. İş görenlerin sahip olması arzu edilen mutluluk, salt iş ortamında sağlanan motivasyon ve olumlu koşullar ile mümkün kılmabilecek bir durum değildir. Çünkü mutluluk, insanın sadece iş hayatı ve örgüt iklimi ile değil, tüm yaşamı ile ilişkili tümel bir kavramdır.

$\mathrm{Bu}$ çalışmada ilkin insanlık tarihi boyunca temel felsefi meselelerden biri olarak irdelenmiş mutluluk kavramının çağlar boyunca nasıl algilandığı ve tanımlandığına bakılacak, ardından bir işletme terimi olarak performans, özel olarak iş gören performansı konusuna değinilecektir. Üçüncü bölümde ise "mutluluğun, iş görenin performansı ile doğru oranth olduğu" hipotezinin geçerliliğini sorgulamaya dönük olarak, Türk Hava Yolları A. O.'da çalşan 203 beyaz yakalı iş gören ile yapılan, literatürde Fordy Mutluluk Ölçeri olarak bilinen anket çalş̧ması sonuçları ile söz konusu personelin puanlamayı yapan birinci amirlerinden edinilen bireysel performans puanları eşleştirilerek hipotezin geçerliliği tartışılacaktır.

\section{MUTLULUK KAVRAMI}

Sokrates'ten beri biliyoruz ki mutluluk, varlk ihtiyacı sorgulanmayacak bir temel özdeğerdir. Yani “insan neden mutlu olmak ister?” şeklinde bir sorunun anlamı bulunmamaktadır. (Macmahon,2013, 43) 
Mutluluk insanoğlunun üzerinde en fazla düşündüğü konulardan birisi olduğu için sayısız tanımı ve tarifi yapılmış̧ır. Descartes, mutluluğu tam bir ruh memnunluğu ve iç hoşnutluğu olarak tanımlar. O mutluluğun erdeme, erdemin de aklın iyi kullanılmasına bağlı olduğunu iddia etmektedir.(Türkben, 2010,1) Belki de en geniş ve kapsayıcı tanımlardan birisi budur. Dolayısıyla insanların ruh memnuniyetini sağlayıcı erdemli ve rasyonel davranış sayısı kadar mutluluk tanımı yaplabilir.

Konfüçyus "mutlu olmak için içinde bulunduğunuz andan daha iyi bir zaman olduğuna karar vermek için beklemekten vazgeçin. Mutluluk bir varış değil, bir yolculuktur. Pekçokları mutluluğu insandan daha yüksekte ararlar, bazları da daha alçakta. Oysa mutluluk insanın boyu hizasmdadır" derken Mahatma Gandi mutluluğu, "düşündüğünüz, söylediğiniz ve yaptığınız şeyin uyum içinde olduğu zamandır" diye tanımlamıştır. (fwmail.net).

Bütün bu tanımların çeşitliliği ve fazlalı̆ı karşısında makalenin konusunun dışına çıkmamak için son olarak Freud'un "çalşsmayı ve sevmeyi mutluluk" olarak tanımladığını belirtmek faydalı olacaktır. (Csikszentmihalyi, 2005,166)

\subsection{Mutluluğun Tarihçesi}

Mutluluk kavramını tarih sahnesinde ilk sorgulayan düşünür Sokrates’tir. Ondan öncesine kadar mutluluk hep şans, talih olarak tanımlanan tanrısal bir olgu iken Sokrates insanların kendi rasyonel düşünüşleri sayesinde hayatları üzerinde egemenlik kurabileceklerini söylemiştir. (Mc Mahon, 2013, 41). Ancak onun fikirlerini yazlı hale getiren öğrencisi Platon olmuştur. Yukarıda da belirttiğimiz üzere Sokrates'in 'Bir insanın mutluluğu neden arzuladığıı sormaya da gerek yoktur” dediğini Plato, "The Symposium”, adlı eserinde bize aktarmıştır.

$\mathrm{Bu}$ iki önemli isimden sonra onların öğrencisi ve belki de düşüncelerini yazll olarak ifade edebildiği için insanlk tarihinin en önemli düşünürü Aristotoles her şeyin bir amaca yönelik olduğunu ve bir mantığa sahip olduğunu iddia eder.

Aristoteles'e göre, erdem, ahlâkın amacını oluşturan mutluluğun kazanılması için yegâne vasitadır. Çünkü mutluluk, erdeme uygun etkinliktir. Bu durumda erdemin mutluluğu elde etmede önemli bir işlevinin bulunduğu son derece açktıtr ( Türkeri, 2005, sy 85).

Daha sonraki dönemde ortaya çıkan iki felsefi okul insanoğlunun tarih boyunca aradığı mutluluğun iki ayrı kaynağını temsil etmişlerdir. Bunlardan ilki Epikür diğeri ise Zenon dur.

Epikür'e göre insanın ruhu da bedeni ile birlikte ebedi olarak yok olacaktır. O halde sonu hiçlik olan bu âlemde yaşanabilecek olan bütün hazlar yaşanmahıır. (Yıldırım, 2012,"giriş"). Yani Epikür, hazcılhğın ya da hedonizmin kurucusudur denilse çok yanlıs olmayacaktır. Günümüze 
kadar gelen mutluluk için hazzın gerektiği (ya da yeter olduğu) düşüncesi Epikür'le başlamıştır. Aynı dönemde Stoa Okulunun kurucusu olan Zenon ise erdemci ve hazlardan uzaklaşan bir mutluluk anlayışı üzerine ağırlik vermiştir.

Mutluluğun kaynağını bulmaya yönelik bu iki ana eğilim hep varolagelmiştir. İki ana okulun en son iki büyük temsilcisi ise Freud ve V. Frankl'dır. Freud'a göre davranışlarımızı yönlendiren itici güç zevktir. Frankl'a göre ise bu güç anlamdır. (Ben-Sharar, 2008, 67)

Modern insan için de bu ikilem devam etmektedir çünkü dünya değişip gelişse de insanın özü ve davranış modelleri o kadar hızh değişmemektedir. Bu noktadan hareketle bir insanın mutluluğu için yukarıda belirtilen iki kaynağın da kullanımı önemli olmaktadır. Yani, bize doyum sağlayan mutlu bir hayat süreceksek hem hayattan zevk alma hem de hayatımıza anlam katma isteğimizi tatmin etmemiz gerekir. (Ben-Sharar, 2008, 67) Tüm hayatın içinde olduğu kadar iş hayatında da, insan, benzer davranışlar sergilemektedir.

\section{2. İş Hayatında Mutluluk}

İnsanın mutluluğu için "akış" kavramını geliştiren "Olumlu Psikoloji”nin öncülerinden Prof. Dr. Mihalyi Csikszentmihalyi aynı isimli eserinde insanların daha fazla mutlu olduklarımı çünkü daha fazla akış yaşadıklarını belirtmektedir. Csikszentmihalyi yıllar süren bilimsel araştırmaları sonrasında insanın mutlu olduğu anların; kendilerini bir etkinliğe başka hiçbirşeyi umursamayacak kadar kaptırdıkları ve kendi sınırlarını zorladıkları anlar olarak belirlemiş bu halin de adına "akış" ismini vermiştir. (Csikszentmihalyi, 2005, 6). Bir insan işinde mutsuzsa bunun 3 nedeni vardır:

1) İnsan, değerli ve zor bir iş yapmadı̆̆ını düşünür.

2) Yöneticilerle ve diğer insanlarla çatışır

3) Yüksek stres altmda tükenir.

Bunların üçü de algısal durumlardır. (Csikszentmihalyi, 2005, 185) . Bu nedenlerden dolayı işyerinde zihnin başka konulara kayması mutluluğu ve verimliliği düşürür. Yöneticiler, çalşanların işlerine konsantre olmalarını sağlayacak yolları öğrenmek isterler. (Killingsworth, 2012, 8)

Maslow, “insanın yaşayabileceği en iyi kader, kazanabileceği en büyük savaş çok sevdiği bir işi yaparken ondan maddi kazanç sağlamasıdır” demiştir. (Ben-Sharar,145 ) Dolayısıyla işini severek yapan, işte çalısırken akışı yaşayan insanlar mutlu insanlardır. İş hayatında çalş̧anlarma "akış"ı yakalatan şirketler bundan sonra daha değerli olacaklardır. (Seligman, 2007,183 ). Bunun da yolu yapılacak işi anlamlı bulan, bu işi yapmaktan zevk alacak ve işin özellikleri kendi değerlerine uygun olan çalısanları istihdam etmekten geçecektir. Ayrıca bu aşamada iyimserlik 
özelliği ağır basan çalşanların başarılı olma oranlarının daha fazla olduğunu gözardı etmeden işe alımlarda bu özelliklere sahip çalısanların tercih edilmesi fayda sağlayacaktır. (Seligman,2011,130). “Ayrıca beynimizin pozitif düşünme konusunda eğitilmesi kaslarımızın jimnastik salonunda eğitilmesinden çok farklı değildir. Nöroplasti üzerinde yapılan son araştırmalar yetişkinlik döneminde bile beynin değişiminin ve yeni alşskanlıklar kazanmanın mümkün olduğu göstermiştir. (Achor, 2012, HBR, 100). Dolayısıyla şirketin çalışanların iyimserlik düzeylerini artırabileceğini bilmesi ve buna göre programlar geliştirmesi faydah olacaktır.

Diğer yandan Harvard Men isimli 70 yll süren araştırmanın ortaya koyduğu sonuç, mutlu insanların ortak özelliklerinin sevgi ve sosyallik olduğudur. Mutlu ve sosyal bir çocukluk geçiren insanların hayatta daha fazla başarı sağladkları ortaya konulmuştur. (Slater, 2012, 1) Bu insanların aynı zamanda başarılı insanlar da olduğunu anlaşılmıştır. Ayrıca iş yerinde insanların orayı sevmesinin en büyük nedeninin birlikte çalıştıları insanlar olduğu anlaşılmıştır. Bu nedenle şirketler çalışanlarına daha sosyal ve paylaşımcı ortamlar sunmaktadırlar. (Shawn, 2013, 37).

$\mathrm{Bu}$ araştırmanın konusu mutluluğun nasıl kazanılacağı ya da korunacağı değil, mutlu insanların bir çalşanan olarak iş yerinde gösterdikleri bireysel performansın düzeyidir. Psikolojik olarak mutlu bir işgücü daha iyi bir bireysel performansı desteklemek anlamma gelebilir. (Rego ve Cunha, 2008, 20).

Buna dair yapılan anket çalışmasının sonuçlarının değerlendirilmesinden önce performans kavramına değinilmesi önem arz etmektedir.

\section{ISSGÖREN PERFORMANSI}

ukarıda değindiğimiz mutluluk kavramı ile ilişkisini sorgulamadan önce işletme literatüründe, çalş̧an performansı, iş gören performansı ya da kısaca performans olarak geçen kavramı tanımlarına göz atılmasında fayda görülmektedir: Performans, belirlenmiş bir zaman içinde yürütülen faaliyetlerin, amaca hizmet etme derecesidir (Akal, 1992: 1).

Perormans, iş görenin işle ilgili çeşitli davranış ve çktıtlarının diğer örgüt üyelerine göre verimlilik düzeyidir (Babin ve Boles 1998: 82).

Performans, kişilerin bir faaliyette hedefe ulaşma derecesidir (Pugh, 1991: 7).

Yine Pugh'a göre performans, görev çerçevesinde önceden belirlenen ölçütleri karşlayacak biçimde, görevin yerine getirilmesi ve amacın gerçekleştirilmesi yönünde ortaya konan mal, hizmet ya da düşüncedir (Pugh, 1991: 7, 8). 
Performans bir faaliyetin sonucunda ortaya konan çktı düzeyidir. Bu düzey, amacm veya görevin yerine getirilme derecesini gösterir (Schermerhorn vd., 1985: 432).

Performans, bir iş görenin gereksinimlerini tatmin etmek için bir işletmede görev ve sorumluluklar üstlenmesi sonucunda, istediklerini elde etmek için zaman ve çaba harcamasıdır (Barutçugil, 2002: 40).

Bir başka ifade ile performans, bir işi yapan bireyin, o işle amaçlanan hedefe yönelik olarak nereye varabildiği, diğer bir ifadeyle neyi sağlayabildiğinin nicel (miktar) ve nitel (kalite) olarak anlatımı şeklinde tanımlanmaktadır (Tnnaz, 1999: 389).

Performans, bireyin işini yerine getirmek için harcamış olduğu tüm çabalar karşısında elde ettiği başarı düzeyidir. Bir kişinin performansı, sahip olduğu nitelikler ve yetenekler ile inanç ve değerlerine bağldır (Morillo, 1990: 270).

Performans, birey için anlamlı olan amaçların oluşturulmuş günlük programlarla adım adım gerçekleştirìmesidir. Bir başka deyişle, görevin gereği olarak önceden belirlenen standartlara uygun davranışların gösterilmesi ve beklenen amaçlara ulaşma derecesidir (Canman, 1993: 7).

Bir başka tanmmlamaya göre performans, belirlenen koşullara göre bir işin yerine getirilme düzeyi veya iş görenin davranış biçimidir. Bir çalısanın belirli bir zaman kesiti içerisinde kendisine verilen görevi yerine getirmek suretiyle elde ettiği sonuçlardır. Bu sonuçlar olumlu ise, personelin kendisine verilen görev ve sorumlulukları başarılla yerine getirdiği ve dolayısıyla yüksek bir performansa sahip olduğu anlaşlitr. Sonuçlar olumsuz ise, iş görenin başarlı olmadığı veya performans düzeyinin düşük olduğu kabul edilir.

Performans, belirli bir zaman birimi içerisinde üretilen mal veya hizmet miktarıdır ve işlevine göre "etkinlik", "verim", "çktı" kavramlarıla ve ayrıca bireyin yeteneği ve motivasyonu arasındaki etkileşimin bir sonucu olarak ifade edilmektedir (Torrington ve Hall, 1995: 316).

Çeşitli beklentilerle bir örgüte katılan birey, bu beklentilerini gerçekleştirebildiği ölçüde işinden ve içinde bulunduğu örgütten memnun olmakta ve böylece verimliliği ve performansı artmaktadır (Nelson ve Quick 1995). Bireysel performans, kişilik, değerler, tutumlar ve bireyin yetenekleri ile azaltılı veya ilımlaşır. Bu faktörlerin birleşimi bireyin alglamasını ve nihayetinde performansmı etkiler (Marchant 1999: 63). Bireyin işinden tatmini ile yakmdan igili olan bu faktörlerin performansla olan ilişkisi, iş tatmini - performans ilişkisini ortaya koymaktadır.

İsgören performansı ile ilgili yapılan pek çok tanımın ortak noktası, performansın bireysel beklenti ile örgütsel amaç arasında kurulan ilişkinin sonucunda ortaya çkmasıdır. İsgörenlerin nitel ve nicel olarak amaçlarına ulaşabilmesi için örgütsel iklime ilişkin bazı psikolojik koşulların bulunması gerekir. Bunun için iş görene, ücret ve kariyer gelişimi gibi maddi olanaklarm sağlanmas1 yanında, örgütsel destek hissinin verilmesi, karara katma gibi kendisini 
gerçekleştirmesine olanak sağlayacak bir örgütsel iklimin sağlanması önem taşımaktadır (Gupta, 1982: 135).

Bireysel performans, örgütün amaçlarma ulaşabilmesi için bireyin kullandığı yetkinliklerdir. $\mathrm{Bu}$ yetkinlikler, yalnızca işe yönelik görevleri değil, işle doğrudan ilişkisi olmayan davranışları da içermektedir. Yetkinlik ise kişinin işletme amaçlarmı gerçekleştirme derecesidir (Mc Grath, 1995: 251).

Performans kavramının anlaşılmasında, performansı etkileyen unsurların neler olduğunun bilinmesi önem taşır. İşgören performansını etkileyen arasında sayılabilecek örgütsel bağlllk, yüksek motivasyon, kurumsal destek, örgütsel iklim, örgütsel külttür gibi örgüt kaynakh ve örgütle sınırh unsurların yanı sıra insan yaşamının tümüyle ilintili ve çalışmamızın konusu olan mutluluk ilk sirada anilabilir.

\subsection{Performans Değerlendirme}

Yukarıda tanımı yapılan performans kavramı, sosyal bilimlerde en yaygın insan kaynakları yönetimi disiplininde yer bulan "performans değerlendirme" ile uygulama alanı bulur. Performans değerlendirme ile genel olarak iş görenin herhangi bir noktadaki etkinliğini ve başarı düzeyini belirlemeye yönelik çalşsmalar kast edilmektedir. Performans değerlendirme, bir yöneticinin önceden saptanmış standartlarla karşılaștırma ve ölçme yoluyla, iş görenlerin işteki performanslarını değerleme sürecidir (Palmer, 1993: 9).

Bir başka tanıma göre performans değerlendirme, iş görenin işletme içinde tarif edilen sınırlar içerisinde ortaya koyduğu başarının ölçülmesidir (Erdoğan, 1991: 155).

İşgören performansının değerlendirilmesi, kurumda görevi ne olursa olsun bireylerin; çalısmalarını, etkililiklerinin, eksikliklerinin, fazlaliklarını, yeterliliklerinin, yetersizliklerinin kısacası iş görenin bir bütün olarak tüm yönleri ile gözden geçirilmesidir (Fnndkçı, 2002: 297).

Performans değerlendirme ile iş gören yetersizliklerinin ortadan kaldırılması için eğitim ihtiyacının planlanması ve hangi geliştirme faaliyetlerinin yapılacağı kararlaştırılır (Tanyaş, 2001: 52).

İşgörenin performansından söz etmek için, öncelikle kişinin tanımlanmış bir işle karşı karşıya gelmesi gerekmektedir. Tanımlanan standarda ulaşma, kişinin iyi performansını ifade ederken, standardın altında kalma da başarısı performansın göstergesi olarak kabul edilmektedir (Yild1z vd., 2008: 240).

Performans değerlendirme, çalışan açısından da çok önemlidir. Özellikle başarılı çalışanlar, çalışmalarının karşılığını görmek ve ödülünü almak isterler. Bütün iyi niyeti ve çalışma gücünü ortaya koyan iş gören, düşük performanshı ve işe karşı ilgisiz bir mesai arkadaşıyla aynı 
şekilde değerlendirildiğini gördüğünde, moral bozukluğu yaşayacak, demotive olacak ve giderek çalş̧ma isteğini kaybedecektir. Performans değerlendirme, bu nedenle, çalşann işe yöneltilmesini, özendirilmesini ve örgüte duyduğu güvenin arttrrlmasını sağlayan bir araç olarak da görülebilir (Cohen vd., 1992: 192).

İşgörenlerle ilgili sorunlar, 19. yüzylln ikinci yarısnda başlayan sanayileşme süreciyle giderek artmış ve sorunların çözz̈müne ilişkin çahşmalar yoğunluk kazanmış̧tr. Bu dönemde büyük ölçekli örgütlerin ortaya çıkısı, kaynakların giderek azalmaya başlaması, toplu üretim tekniklerinin kullanılmaya başlanması ve teknolojik yeniliklerin hılanmasıyla birlikte işgücünden daha üst düzeyde yararlanma zorunluluğu ortaya çkmıştır (Eryılmaz, 2000: 245).

Örgütlerde iş görenlerin performanslarmm sistematik bir biçimde değerlendirilmesi uygulamaları, 1900'lü yilları başlarnnda Amerikan ordusunun değişik birimlerinde adam-adama değerleme yönteminin geliştirilmesiyle başlamıştır (Murphy ve Cleveland, 1995: 5).

Yine 20. Yüzyllın ilk çeyreğinde sanayi şirketlerinde birim saat ücretinin rasyonel biçimde belirlenmesine ilişkin yapılan çalşmalar performans değerlendirme sisteminin gelişimine katkı sağlamıştrr. Bunu takip eden çalş̧malarla iş görenlere yapılan hakediş ödemesinin, başarı kriterine göre hesaplanması uygulamasına geçilmiş̧ir (Erdoğan, 1991: 168).

1980'li yllardan itibaren performans değerlendirme uygulamalarında bilişsel yaklaşım ön plana çıkmıştr. Bu yaklaşıma temel oluşturan bilişsel psikoloji görüşüne göre; düşünme, hissetme, öğrenme, anmmsama, karar verme, dil, problem çözme ve yarglama gibi zihinsel süreçler incelenmekte, insanları bilgiyi anlama ve saklama becerileri, davranışlarını gözlemlenmesi ile değerlendirilmektedir. Son 20 yl içindeki çalş̧malar ise daha çok performansın kavramsal ve işlevsel tanımı, boyutları, değerlendirme kaynağı ve değerlendiricileri üzerinde odaklanmıştrr.

Doğrudan mutlulukla performans arasındaki ilişkiyi inceleyen çok fazla sayıda araştırma bulunamamıştr. Yapılan çalş̧alar daha çok liderlik özellikleri ile çalşanların bireysel performansları arasındaki ilişki üzerinedir. Bununla birlikte yapılan smırh sayıdaki araştrrmada, mutlulukla bireysel performans arasında pozitif bir ilişki olduğu sonucuna varlmışıtr. Yüksek coşku ve isteğe sahip çalşanlar daha yüksek bireysel performans göstermektedirler. Bu çkt,, kanttlarla istikrarh bir şekilde desteklenerek iddia edilebilir ki diğerlerine göre daha mutlu çahşanlar iş konusunda kendilerini geliştirme ve ilerletme konusunda daha iyi durumdadırlar. Daha çoşkulu ve gayretli çalşanların kendilerini işlerine daha fazla adamaları akla çok yatkındır (Rego ve Cunha, 2008, 19). Yapılan çalş̧alar daha çok liderlik özellikleri ile çalşanları bireysel performansları arasındaki ilişki üzerinedir. 


\section{UYGULAMA}

\subsection{Metodoloji}

Çalşsma, Türkiye'nin en büyük ve en eski hava yolu şirketi olan Türk Hava Yolları A. O.'nun İstanbul Yeşilköy’de bulunan Genel Müdürlük binasında çalşsan beyaz yakalı personel ile sinırlandırılmıştır. $\mathrm{Bu}$ yapıda görev yapan yaklaşı 1.000 çalşan arasından tesadüfí örneklem ile 203 çalşan ile literatürde Prof. Martin Seligman'ın Fordy Mutluluk Ölçeri olarak bilinen anket çalışması yapılmış, söz konusu 203 çalışanın 5'li Likert Ölçeği'ne göre bireysel performans puanları, puanlamayı yapan birinci amirlerinden edinilerek söz konusu anket çıtıları ile eşleştirilmiştir.

\subsection{Anket Sonuçlarının Analizi}

Tablo 1. Mutluluk Frekans Tablosu

\begin{tabular}{|c|c|c|c|}
\hline & $\mathrm{F}$ & $\%$ & Kümülatif \% \\
\hline 1,00 & 1 &, 5 &, 5 \\
3,00 & 13 & 6,4 & 6,9 \\
4,00 & 4 & 2,0 & 8,9 \\
5,00 & 26 & 12,8 & 21,7 \\
6,00 & 15 & 7,4 & 29,1 \\
7,00 & 58 & 28,6 & 57,6 \\
8,00 & 79 & 38,9 & 96,6 \\
9,00 & 3 & 1,5 & 98,0 \\
10,00 & 4 & 2,0 & 100,0 \\
Toplam & 203 & 100,0 & \\
\hline
\end{tabular}

Öncelikle mutluluk frekans tablosuna baktı̆̆ımıda iş görenlerin büyük bir bölümünün mutlu olduğunu söyleyebiliriz. 10'lu ölçekte (1 “çok mutsuz", 10 “çok mutlu") kendisini mutsuz olarak tanımlayan (5'in altında not veren) iş görenlerin oranı sadece $\% 8.9$ dur. Ayrıca 10 üzerinden kendi mutluluğunu 8 olarak tanımlayan çalışanlar en büyük grubu oluşturmaktadır. (\% 38.9).

Tablo 2. Performans Frekans Tablosu

\begin{tabular}{|c|c|c|c|}
\hline & $\mathrm{F}$ & $\%$ & Kümülatif \% \\
\hline 1,00 & 1 &, 5 &, 5 \\
2,00 & 7 & 3,4 & 3,9 \\
3,00 & 67 & 33,0 & 36,9 \\
4,00 & 91 & 44,8 & 81,8 \\
5,00 & 37 & 18,2 & 100,0 \\
Toplam & 203 & 100,0 & \\
\hline
\end{tabular}


Performans frekans tablosundan anlaşlacağı üzere çalş̧anların büyük bir bölümünün bireysel performans puanları oldukça yüksektir. 5'li ölçekte 4 ve üzeri not alanların oranı toplam \% 63 tür. 1 ve 2 yani düşük performans gösterenlerin oranı ise sadece \%3.9 dur.

Mutluluk ve performans açısından oluşan olumlu durumu aşağıdaki histogramlardan daha net anlayabiliriz.

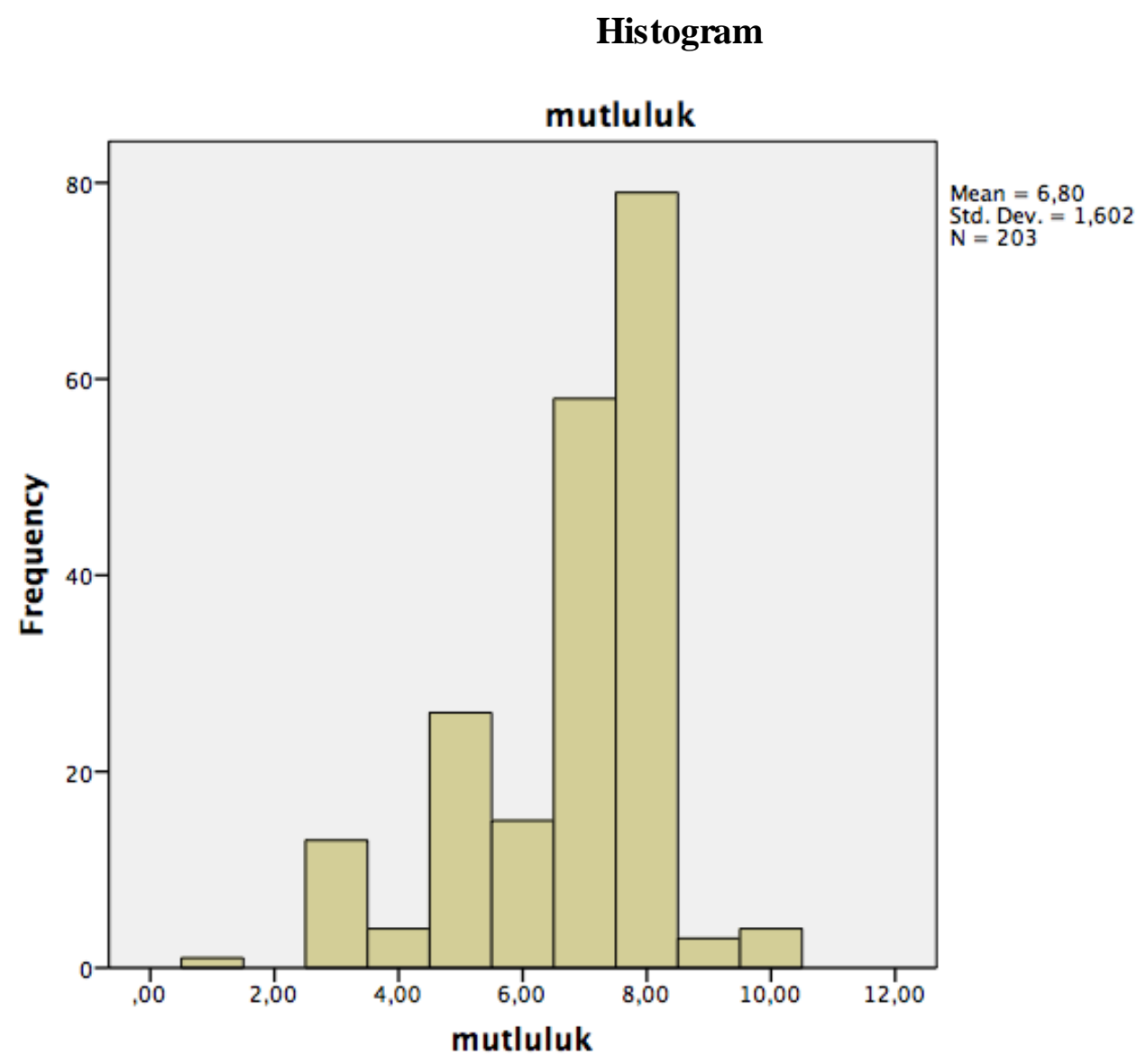




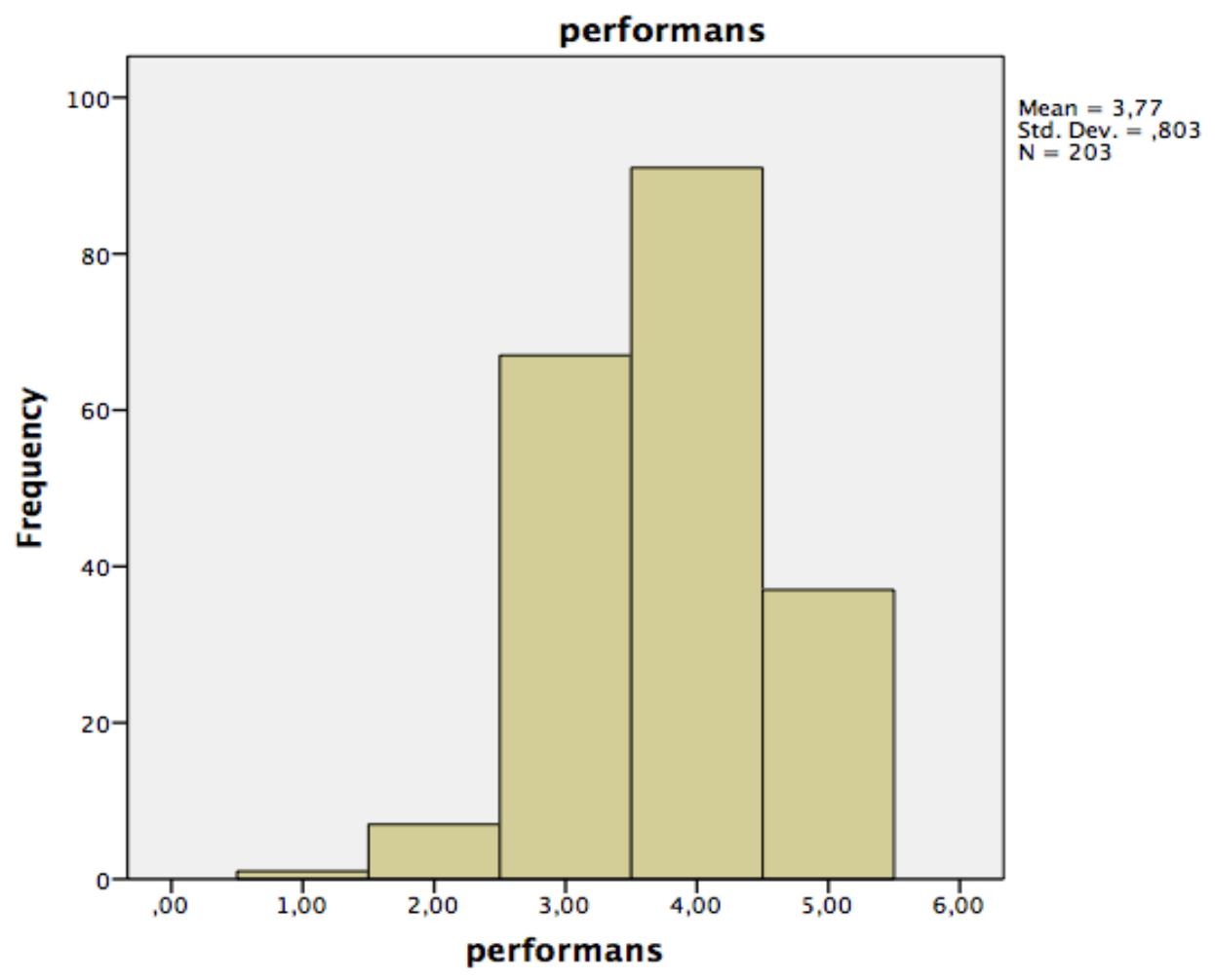

Ankette yer alan mutluluk ve performans değerlerinin ikisi de nominal olduğu için bu iki değişken arasında bir ilişkinin olup olmadığını anlamlı şekilde ortaya koyabilmek için çapraz 160 tablolar çıkarılıp Ki-kare Testi uygulanmalıdır.

Tablo 3. Mutluluk x Performans Çapraz Tablo Karşılaştırması

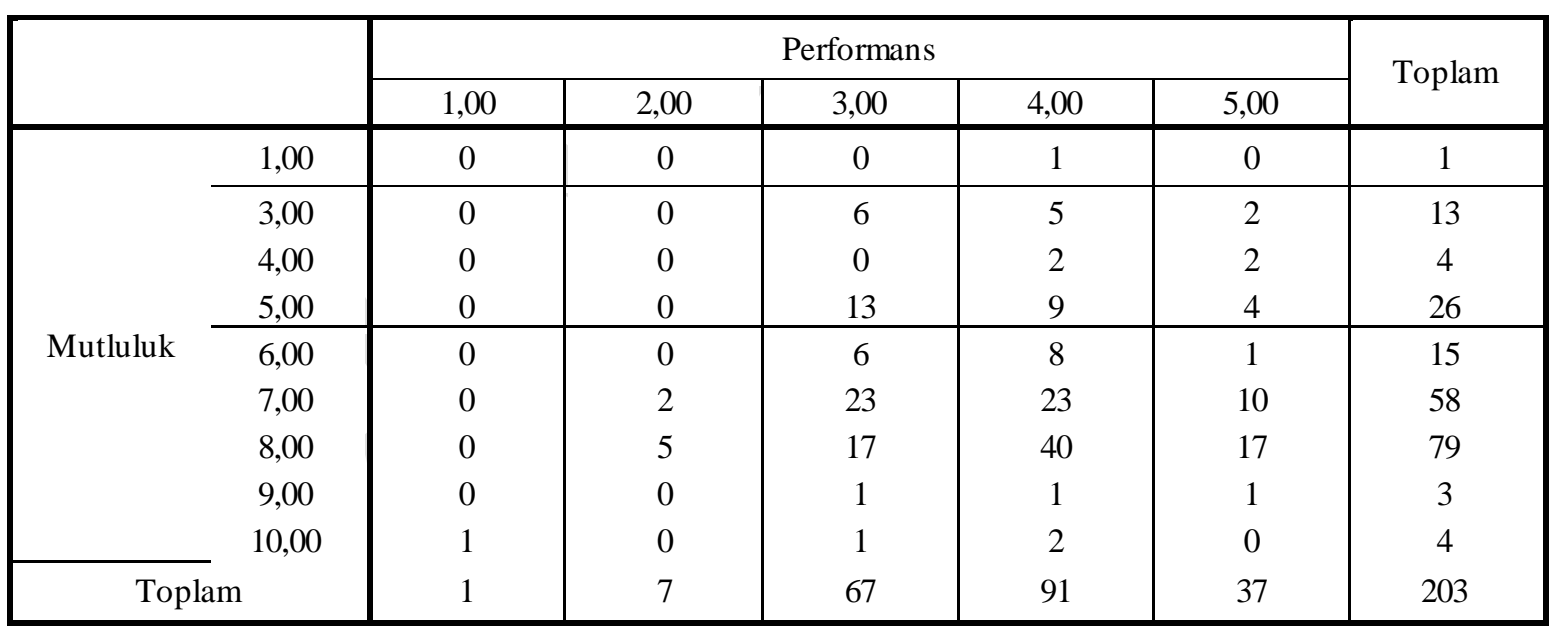


Tablo 4. Ki-Kare Analiz Sonuçları

\begin{tabular}{|c|c|c|c|}
\hline & Value & df & Asymp. Sig. (2-sided) \\
\hline Pearson Chi-Square & $70,764^{\mathrm{a}}$ & 32 &, 000 \\
Likelihood Ratio & 32,738 & 32 &, 431 \\
Linear-by-Linear &, 009 & 1 &, 924 \\
Association & 203 & & \\
\hline N of Valid Cases & & & \\
\hline
\end{tabular}

a. 35 cells $(77,8 \%)$ have expected count less than 5 . The minimum expected count is, 00 .

Çift taraflı $\mathrm{p}$ değeri 0.05 den küçük olduğu için $(\mathrm{P}=0.00)$ ikisi arasında bir ilişki vardır denilebilir. Ancak bu değer yanıltıcı olacaktır. Çünkü çapraz tablolarda 1 ve 2 değerlerinde çok fazla " 0 " değeri bulunmaktadır. $\mathrm{Bu}$ durumda iki değişken arasında doğrusal bir ilişkinin olduğunu söyleyebilmemiz bilimsel olarak doğru olmayacaktır. Mutluluk algisal bir değer olduğu için daha fazla sayıda soru içeren anket setinin uygulanması yerinde olacaktır.

\section{SONUÇ}

İnsanlk tarihi boyunca insanoğlunun en büyük arayışlarmdan birisi olarak kabul edilen mutluluğun diğer pek çok alan gibi insanın iş hayatındaki başarısını da etkilemesi oldukça doğaldır. İş hayatında, genel olarak daha mutlu insanların daha yüksek bireysel performans sonuçlarına ulaşmalarını beklemek yanlış olmayacaktır.

Örgüt başarısını performans belirteçleri ile ölçüldüğü günümüz dünyasında, örgütlerin temel varlk kaynağı olan iş görenlerin bireysel performanslarını, iş göreni, iş dünyası bağlamından soyutlayarak "insan" olarak ele alan ve tümel bir kavram olan mutluluk'la olan bireysel iyelik düzlemindeki ilişkisini sorgulayan bu çalışmada, uygulanan anket sonuçları değerlendirildiğinde bireysel mutluluk ile iş gören performansı arasındaki ilişkinin olduğu ancak bilimsel açıdan kesinlik arz edecek düzeyde olmadı̆̆ı sonucuna varılmıştır. Bunun nedeni, incelenen ana kavram olan mutluluğun algısal bir değişken olmasıdır. Ayrıca mutluluk ve bireysel performans ölçüm sonuçlarının nominal değerler olması da anket çalşması çıtısının bilimsel kesinlik arz etmesini zorlaştırmıştır. Mutlulukla bireysel performans arasındaki ilişkinin bilimsel olarak daha yüksek güvenilirlikle ortaya konulabilmesi için Fordy Mutluluk Ölçeri yerine zenginleştirilmiş farkh bir soru setinin kullanılması gerektiği sonucuna varılmıştır. 


\section{KAYNAKÇA}

AKAL, Z. (1992), İşletmelerde Performans Ölçüm ve Denetimi: Çok Yönlü Performans Göstergeleri, MPM Yayınları, Ankara.

BABIN, B. J. ve BOLES J. S. (1998). Employee Behavior in a Service Environment: A Model and Test of Potential Differences between Men and Women. Journal of Marketing 62: 77-91.

BEN-SHARAR, T. (2008), Daha Mutlu Yaşamak, Elma Yayınları, İstanbul.

BARUTÇUGİL, İ. (2002), Performans Yönetimi, Kariyer Yayıncıllk İletişim Eğitim Hizmetleri Ltd. Şti., İstanbul.

BENLİGíRA Y, S. (2004), İnsan Kaynakları Yönetimi, Anadolu Üniversitesi Yayınları, İstanbul.

CANMAN, A. D. (1993), Personelin Değerlendirilmesinde Çağdaş Yaklaşımlar ve Türkiye'de Kamu Personelinin Değerlendirilmesi, TODAİE Yayınları, No:252, Ankara.

COHEN, A. R., FINK, S. L., GADON N., WILLITS, R. D. (1992), Effective Behavior in Organizations. 5th edition, Homewood, IL: Richard D. Irwin, Inc. USA.

CSIKSZENTMIHA LYI, M. (2005), Akış, Mutluluk Bilimi, HYB Basın Yayım, Ankara.

ERDOĞAN, İ. (1991), İşletmelerde Personel Seçimi ve Başarı Değerleme Teknikleri, İ.Ü., Yayın No: 248 , İstanbul. ERYILMAZ, B. (2000), Kamu Yönetimi, Erkam Matbaası, İstanbul.

FINDIKÇI, İ. (2002), İnsan Kaynakları Yönetimi, Alfa Basım Yayım, İstanbul.

GUPTA, O. P. (1982), Commitment to Work of Industrial Workers, Concept Publishing Company, New Delh i.

KILLINGSWORTH, M. (2012), The Future Of Happiness Research, Harward Business Review, January -February.

M. MACMAHON, D. (2013), Mutluluk: Mutluluk Üzerine Tarihsel bir Çalışma, e Yayınları, İstanbul.

MARCHANT, T. (1999), Strategies For Improving Indıvidual Performance And Job Satisfaction At Meadowvale Health, Journal of Management Practice 2/3: 63-70.

Mc GRATH, R. G. (1995), Defining and Developing Competence, Strategic Management Journal, Vol. 16, No.4, s.251.

MORILLO, C. R. (1990), The Reward Event and Motivation, The Journal of Philosophy, Vol.87, No.4, s.270.

MURPHY K. R., CLEVELAND J. N. (1995), Understanding Performance Appraisal Social, Organizational and Goal-Based Perspectives, Sage Publ., USA.

NELSON, D. L. ve QUICK J. C. (1995), Organizational Behavior: Foundations, Realities, and Challenges. Alternate Edition. West Company, New York.

PALMER, M. J. (1998), Performans Değerlendirmeleri, Rota Yayınları, İstanbul.

PUGH, D. (1991), Organizational Behaviour, Prentice Hall International (UK) Ltd., London.

REGO A. ve CUNHA M.P. (2008), Perceptions of Authentizotic Climates and Employee Happiness: Pathways to Individual Performance, Journal of Business Research, Volume 61, Issue, July 2008, USA 
SCHERMERHORN, J.R., HUNT, G., OSBORN, R.N. (1985), Managing Organizational Behavior, John \& Sons Publishing, New York.

SELİGMAN, M. (2007), Gerçek Mutluluk, HYB Basın Yayım, Ankara.

SELIGMAN, M. (2011), Öğrenilmiş İyimserlik, HYB Basın Yayım, Ankara.

SHAWN, A. (2012), Positive Intelligence, Harward Business Review, January-February 2012.

SHAWN, A. (2013), Mutluluk Avantajı, MediaCat Yayınları, Ankara.

SLATER, D. (2012), What Harvard's Grant Study Reveals about Happiness and Life, , The Daily Beast, Articles.

TANYAŞ, M. (2001), İnsan Kaynakları Yönetimi, İstanbul Teknik Üniversitesi, 52- 94, İstanbul.

TINAZ, P. (1999), Performans Degerleme Sistemlerinin Önemi ve Türkiye’deki Uygulamalarına İlişkin Bir İnceleme, Celal Bayar Üniversitesi, İktisadi ve İdari Bilimler Fakültesi Dergisi, Say1:5, 389-406, Manisa.

TORRINGTON, D. ve HALL, L. (1995), Personel Management: HRM in Action, Prentice Hall International (UK) Ltd., 3. Print, London.

TÜRKBEN, Y. (2010), Descartes'in Ahlak ve Mutluluk Anlayışı, Hikmet Yurdu Dergisi, Ocak-Haziran.

TÜRKERİ, M. (2005), Aristoteles’in Etiğinde "Nefsine Hâkim Olma” ve “Erdem” ile İlişkisi, D.E.Ü.İlahiyat Fakültesi Dergisi, Sayı XXI, 77-9, İzmir.

YILDIRIM, A. (2012), Epikürizm ve Baki’nin Bir Gazeli Üzerine, International Periodical For The Languages, Literature and History of Turkish or Turkic Volume 7/3, Summer 2012, p. 2701-2709, Ankara.

YILDIZ, O., DAĞDEVIREN, M., ÇETİNYOKUŞ, T. (2008), İşgören Performansının Değerlendirilmesi İçin Bir Karar Destek Sistemi ve Uygulamas1, Gazi Üniversitesi Müh. Mim. Fak. Dergisi, Cilt 23, No. 1, s.239-248, Ankara. www.fwmail.net, Mutluluk hakkında düşündürücü sözler, 20.12.2013 tarihli yayın. 